\title{
Enzymologic Studies on Patients with Methylmalonic Aciduria: Basis for a Clinical Trial of Deoxyadenosylcobalamin in a Hydroxocobalamin-Unresponsive Patient
}

\author{
R. A. CHALMERS, M. D. BAIN, J. MISTRY, B. M. TRACEY, AND C. WEAVER
}

Department of Child Health, St. George's Hospital Medical School, London, Medical Research Council Clinical Research Centre, Harrow, and Department of Paediatrics, University Hospital of Wales,

Cardiff, United Kingdom

\begin{abstract}
Eleven patients with methylmalonic aciduria have been classified on the basis of detailed enzymology on cultured skin fibroblasts. Nine were classified as mutase deficiencies and were unresponsive to hydroxocobalamin in vivo or in vitro. One was classified as a $\mathrm{Cbl} \mathrm{A}$ variant and was responsive to hydroxocobalamin therapy in vitro and in vivo. Patient 11 was classified as having deoxyadenosyltransferase deficiency (Cbl B). However, a clinical therapeutic trial of deoxyadenosylcobalamin resulted in no clinical or biochemical improvement. Further studies on the patient's cultured fibroblasts suggested that deoxyadenosylcobalamin fails to reach the mitochondria in an intact form. These studies show that detailed enzymologic classification is essential for the reliable evaluation of the response to therapeutic maneuvers; complementation studies alone may be inadequate to completely classify these patients. Therapy with deoxyadenosylcobalamin offers no advantages over the use of hydroxocobalamin in the treatment of patients with methylmalonic aciduria. (Pediatr Res 30: 560-563, 1991)
\end{abstract}

Abbreviations

OHCbl, hydroxocobalamin

AdoCbl, deoxyadenosylcobalamin

Methylmalonic aciduria characterizes a group of disorders that occur because of deficient activity of methylmalonyl CoA mutase, a mitochondrial enzyme with a specific requirement for $5^{\prime}$ AdoCbl as cofactor $(1,2)$. Recognized causes of methylmalonyl CoA mutase deficiency include defects in the biosynthesis of the enzyme protein itself with absence of enzyme protein or abnormal protein with reduced or absent catalytic activity, reduced cofactor binding capacity, and defects in the uptake into the mitochondria of the proenzyme or in the biosynthesis of the cobalamin cofactor (2). Disorders in the biosynthesis of the cofactor include defective release of the precursor $\left(\mathrm{Co}^{\mathrm{III}}\right) \mathrm{OHCbl}$ from the lysosome after endocytic uptake of transcobalamin$\mathrm{OHCbl}$ into the cell $(3,4)$, defects in the cytosolic or mitochondrial reductases responsible for reducing $\mathrm{Co}^{\mathrm{III}}$ to $\mathrm{Co}^{\mathrm{II}}$ and $\mathrm{Co}^{\mathrm{I}}$, respectively, and deficient activity of $5^{\prime}$-deoxyadenosyltransferase (5). These defects in the activity of methylmalonyl CoA

Received January 25, 1991; accepted July 18, 1991.

Correspondence and reprint requests: Dr. R. A. Chalmers, Department of Child Health, St. George's Hospital Medical School, Cranmer Terrace, London, SW 17 ORE. mutase are distinguishable by detailed enzymologic studies and by complementation studies in cultured skin fibroblasts: mutase deficiencies are classified as mut ${ }^{\circ}$ (no mutase activity under saturating cofactor concentrations) and mut $^{-}$(some residual activity) and other disorders involving cobalamin defects as $\mathrm{Cbl}$ mutants $[\mathrm{Cbl} \mathrm{A}$ (mitochondrial reductase deficiency), $\mathrm{Cbl} \mathrm{B}$ (deoxyadenosyltransferase deficiency), Cbl F (defective lysosomal release of $\mathrm{OHCbl}$ ), and $\mathrm{Cbl} \mathrm{C}$ and $\mathrm{D}$ (defective cytosolic reductase, associated with homocystinuria)].

Some patients with cobalamin defects may respond biochemically and clinically to pharmacologic doses of vitamin $B_{12}$ (OHCbl), with more than $90 \%$ of $\mathrm{Cbl} \mathrm{A}$ patients showing a marked response and a subsequent favorable clinical course (6). However, fewer than $40 \%$ of $\mathrm{Cbl} \mathrm{B}$ patients respond to $\mathrm{B}_{12}$ therapy and show a relatively poor clinical course. The reasons for the variable responses in the latter group of patients are unclear and illustrate the heterogeneity of the disorder. Most patients with methylmalonic aciduria have been treated with OHCbl, although one or two patients have received AdoCbl. Batshaw et al. (7) reported an unsuccessful response to adenosylcobalamin therapy in a $\mathrm{Cbl} \mathrm{B}$ patient, but more recently Bhatt et al. (8) reported briefly that a patient unresponsive to $\mathrm{OHCbl}$ had shown an improvement during adenosylcobalamin therapy. The latter patient was not, however, clearly classified, although plasma cobalamin analysis showed complete absence of adenosylcobalamin before therapy.

We report here detailed enzymologic studies on cultured skin fibroblasts from 11 patients with methylmalonic aciduria that permitted subdivision in accord with the conventional complementation groups: Results from one cell line suggested that the patient concerned had adenosyltransferase deficiency and might respond in vivo to AdoCbl therapy. Results of a therapeutic trial of AdoCbl are reported together with further studies on the patient's cells in culture. Our results suggest that the cofactor is unable to enter the cells in an unchanged form, and we conclude that adenosylcobalamin therapy offers no advantages over $\mathrm{OHCbl}$ therapy for the treatment of patients with methylmalonic aciduria. We suggest that $\mathrm{Cbl} \mathrm{B}$ patients who respond to $\mathrm{OHCbl}$ therapy have a different molecular defect from that in unresponsive patients. These results have been reported in brief abstract form elsewhere (9). Studies were approved where appropriate by the Harrow Health District Ethical Committee.

\section{PATIENTS AND METHODS}

Patients. Eleven patients with isolated methylmalonic aciduria were studied. All had been diagnosed using gas chromatographymass spectrometry on the basis of methylmalonic aciduria (and associated abnormal organic aciduria including methylcitrate 
diastereoisomer excretion), without homocystinuria, and by enzymology on cultured skin fibroblasts based upon incorporation of $\left[1-{ }^{14} \mathrm{C}\right]$ propionate into acid insoluble material (protein) in intact cells actively dividing in culture. One patient (patient 10 in this study) had shown a marked clinical and biochemical response to $\mathrm{OHCbl}$ therapy (urine methylmalonate off treatment $126.2 \mathrm{mmol} / \mathrm{d}$ reducing to $6.9 \mathrm{mmol} / \mathrm{d}$ while on $7.5 \mathrm{mg}$ intramuscular $\mathrm{OHCbl} / \mathrm{d}$; plasma methylmalonate off treatment 686 $\mu \mathrm{mol} / \mathrm{L}$, on treatment $165 \mu \mathrm{mol} / \mathrm{L}$ ). None of the other patients had shown more than a transient and unsustained response to $\mathrm{B}_{12}$ in vivo. Four of the patients had died, but the remainder are alive in varying clinical conditions, maintained variously on dietary protein restriction with amino acid supplements, L-carnitine, and metronidazole (10). One of the mut ${ }^{\circ}$ patients and patient 11 were described by Bain et al. (10) in reference to metronidazole therapy. The OHCbl-responsive patient is maintained solely on oral $\mathrm{OHCbl}$ and is alive and well at age $15 \mathrm{y}$.

Case report. The patient of particular interest in the present study (patient 11) was a girl who originally presented with recurrent vomiting and failure to thrive in the 1 st month of life. She was diagnosed with methylmalonic aciduria at the age of 6 mo and, being unresponsive to $\mathrm{OHCbl}$ therapy, was treated with a low-protein diet supplemented with amino acids, vitamins, and minerals. She has had repeated admissions to hospital but, although initial development was slow, she now attends a normal school and is making relatively good progress, despite continuing dietary problems and reduced renal function. She showed some clinical improvement on L-carnitine and has recently shown marked improvement on metronidazole therapy, with improved appetite, behavior, and general well-being; she is maintained on her dietary restriction, L-carnitine and metronidazole.

Methods. Skin fibroblasts were cultured in Eagle's minimum essential medium (no $\mathrm{B}_{12}$ ) with $10 \%$ FCS, nonessential amino acids, penicillin, and streptomycin. Cells were harvested with trypsinization and washed with PBS before further study as described below. All additions of cobalamins and cell culture with added cobalamin were carried out in the dark. All cell lines studied were free from mycoplasma contamination.

Propionate incorporation in intact cells was measured by seeding cells into $25-\mathrm{cm}^{2}$ Falcon flasks and subculturing for $3 \mathrm{~d}$ in minimum essential medium as above; cells were washed with PBS and incubated at $37^{\circ} \mathrm{C}$ for $18 \mathrm{~h}$ in PBS containing $15 \% \mathrm{FCS}$, $0.2 \%$ glucose, and $2 \mu \mathrm{Ci} / 1 \mu \mathrm{mol}\left[1-{ }^{14} \mathrm{C}\right]$ propionate. Incorporation of $\left[1,4-{ }^{14} \mathrm{C}\right]$ succinate was measured as control. The cell monolayer was fixed at the end of the incubation by removing the medium, adding $1 \mathrm{~mL} 10 \%$ trichloroacetic acid solution, and incubating in the cold for $0.5 \mathrm{~h}$. The trichloroacetate was removed, and the cell layer washed twice with PBS and then dried at $37^{\circ} \mathrm{C}$. The cell monolayer was dissolved in $1.0 \mathrm{~mL} 2 \% \mathrm{Na}_{2} \mathrm{CO}_{3}$ in $0.1 \mathrm{M} \mathrm{NaOH}$, and the radioactivity in the solution was determined by liquid scintillation counting. Protein content was determined using a modified Lowry assay, and the results were expressed as pmol substrate incorporated $/ \mathrm{mg}$ protein $/ \mathrm{h}$. Incorporation was measured with and without added $\mathrm{OHCbl}$.

Methylmalonyl CoA mutase activity was measured directly on cell sonicates in the presence of $5^{\prime}$-AdoCbl by measurement of the incorporation of [methyl- $\left.{ }^{14} \mathrm{C}\right]$ methylmalonyl $\mathrm{CoA}$ into succinyl CoA. Cell sonicates were incubated at $\mathrm{pH} 7.4$ for $30 \mathrm{~min}$ to $1 \mathrm{~h}$ with $12.9 \mathrm{nCi} / 36 \mathrm{nmol}$ methylmalonyl $\mathrm{CoA}$ and the reaction was stopped and $\mathrm{COA}$ esters were hydrolyzed by addition of $5 \mathrm{mmol} / \mathrm{L} \mathrm{KOH}$ and incubation at $37^{\circ} \mathrm{C}$ for $15 \mathrm{~min}$. Unlabeled (carrier) methylmalonate and succinate were added, followed by acidification with $5 \mathrm{~mol} / \mathrm{L} \mathrm{HClO}_{4}$. The mixture was chilled, and potassium perchlorate, protein, and particulate matter were removed by centrifugation to produce a clear supernatant. Methylmalonate and succinate were separated by reversed phase HPLC using a Varian 5000 HPLC equipped with a multidiode array detector (Hewlett-Packard Co., Palo Alto, CA) operated at $210 \mathrm{~nm}$, on a MOS-Hypersil $5-\mu \mathrm{m}\left(\mathrm{C}_{8}\right) 20 \mathrm{~cm} \times 2.1 \mathrm{~mm}$ inner diameter column (Hewlett-Packard) fitted with a guard column, using $0.05 \mathrm{M}$ phosphoric acid containing $1 \%$ methanol as solvent (flow rate $200 \mu \mathrm{L} / \mathrm{min}$ ). Succinate and methylmalonate eluted within 4-7 min; radioactivity was determined in collected $90-\mu \mathrm{L}$ fractions, and the results were plotted and combined for the appropriate peaks. Final results are expressed as nmol succinate (succinyl $\mathrm{CoA}$ ) produced $/ \mathrm{mg}$ protein $/ \mathrm{h}$.

Control fibroblast lines were obtained from the National Institute of General Medical Sciences Human Genetic Mutant Cell Respository, Camden, NJ, and from local children without demonstrable genetic disease undergoing minor surgical operations. They were selected to match the age range of the patients concerned (cell lines GM 302, GM 409, GM497, GM 500, GM969, and GM 970; age range $3 \mathrm{~d}$ to $10 \mathrm{y}$ ).

Plasma and erythrocyte cobalamins were measured using previously published procedures (11), and the patient's biochemical response to the treatment was monitored by measurement of urinary organic acids determined using capillary gas-liquid chromatography of diethylaminoethyl Sephadex extracts (12).

\section{RESULTS}

In vitro enzymology. Eight of the cell lines studied (patients 1 8) showed no detectable activity of methylmalonyl CoA mutase when assayed in the presence of saturating concentrations of $5^{\prime}$ $\mathrm{AdoCbl}$ and were classified $\mathrm{as} \mathrm{mut}^{\circ}$ variants. One cell line (from patient 9) showed some residual activity under these conditions and was classified as a mut variant. Cells from patient 10 , who was responsive to $\mathrm{OHCbl}$ in vivo, showed normal activity under these conditions, as did cells from patient 11 (Table 1). Cells from both of the latter patients showed increasing mutase activity as adenosylcobalamin concentrations were increased.

Propionate incorporation in intact cells was minimal under basal conditions in all cell lines. Cells from patient 10 showed increasing levels of propionate incorporation in intact cells cultured in the presence of increasing concentrations of $\mathrm{OHCbl}$ (Table 2), consistent with his responsiveness in vivo. Patient 10 was assumed from these results to have a $\mathrm{Cbl} \mathrm{A}$ mutation affecting mitochondrial cobalamin reduction with normal deoxyadenosyltransferase activity, inasmuch as his cells were clearly able to convert added $\mathrm{OHCbl}$ into adenosylcobalamin to restore mutase activity. However, cells from patient 11 (and mut ${ }^{\circ}$ pa-

Table 1. Methylmalonyl CoA mutase activity (nmol succinyl

CoA produced/mg protein $/ \mathrm{h}$ ) in fibroblast sonicates from patients with methylmalonic aciduria in presence of increasing concentrations of $\mathrm{AdoCb}{ }^{*}$

\begin{tabular}{lrrrrc}
\hline & \multicolumn{5}{c}{ Cofactor concentration $(\mu \mathrm{mol} / \mathrm{L})$} \\
\cline { 2 - 6 } & 0 & $10^{-5}$ & $10^{-3}$ & $10^{-1}$ & Saturating \\
\hline Patient 10 (Cbl A) & 0 & 0 & 54 & 106 & 254 \\
Patient 11 (Cbl B) & 0 & 13 & 40 & 82 & 124 \\
Controls & 0 & 0 & 23 & 68 & $138 \pm 12$ \\
\hline
\end{tabular}

$* n=3$ lines, assayed in duplicate; values are median or mean \pm SD (10 lines studied in duplicate). Saturating concentration of AdoCbl was $1.6 \mu \mathrm{mol} / \mathrm{L}$. All assays were carried out in the dark.

Table 2. Propionate incorporation into protein (pmol propionate incorporated/mg protein/h) in intact fibroblasts in monolayer culture cultured in presence of increasing concentrations of $\mathrm{OHCbl}^{*}$

\begin{tabular}{lrrrr}
\hline & \multicolumn{3}{c}{ Cofactor concentration $(\mu \mathrm{mol} / \mathrm{L})$} \\
\cline { 2 - 5 } & 0 & $7 \times 10^{-3}$ & $7 \times 10^{-2}$ & $7 \times 10^{-1}$ \\
\hline Patient 10 (Cbl A) & 82 & 301 & 407 & 585 \\
Patient 11 (Cbl B) & 52 & 50 & 44 & 52 \\
Mut $^{\circ}$ patients & 45 & 34 & 40 & 39 \\
Controls & 804 & 674 & 703 & 834 \\
\hline
\end{tabular}

$* n=3$ lines, assayed in duplicate; values are medians. All cultures and assays were carried out in the dark. 
tients' cells) showed no increased incorporation under similar conditions despite normal mutase activity when measured directly in cell sonicates under saturating cofactor concentrations; on the basis of these results, patient 11 was assumed to have a deficiency of deoxyadenosyltransferase activity (Cbl B variant). The responsiveness of her cell sonicates to AdoCbl suggested that she might benefit from AdoCbl therapy.

Clinical trial of deoxyadenosylcobalamin in patient 11. The therapeutic trial of AdoCbl was carried out in hospital. Informed consent was obtained from her parents before the trial. Two d after admission, she was given $4 \mathrm{mg}$ AdoCbl (Cobanzyme; SAS Pharmaceuticals, Beaconsfield, UK) i.v. followed by a further 4 $\mathrm{mg}$ intramuscularly $5 \mathrm{~h}$ later. She was maintained on $8 \mathrm{mg}$ AdoCbl intramuscularly/d for $9 \mathrm{~d}$. Other treatments remained unaltered throughout the study.

Plasma and erythrocyte cobalamin levels before AdoCbl therapy were 338 and $170 \mathrm{ng} / \mathrm{L}$, respectively (free $\mathrm{B}_{12}$ binding capacity $3409 \mathrm{ng} / \mathrm{L}$ ) (normal values are 190-700, 105-230, and 1200$2000 \mathrm{ng} / \mathrm{L}$, respectively). During administration of AdoCbl, concentrations rose maximally to $>9000 \mathrm{ng} / \mathrm{L}$ in plasma and 2879 $\mathrm{ng} / \mathrm{L}$ in erythrocytes (free $\mathrm{B}_{12}$ binding capacity $780 \mathrm{ng} / \mathrm{L}$ ). There were substantial concentrations of AdoCbl in her erythrocytes, although the individual cobalamins were not quantified separately. However, although urinary methylcitrate concentrations fell slightly for a short period, urinary methylmalonate concentrations rose (Fig. 1) and there was no significant biochemical (or clinical) response to AdoCbl therapy.

Further studies on fibroblasts from patient 11. The lack of response in vivo to AdoCbl therapy despite normalization of mutase activities in cell sonicates by addition of cofactor prompted further studies of cells from patient 11. Propionate incorporation studies were carried out in the presence of saturating concentrations of AdoCbl during the 18 -h incubation in cells from patients 11 and 10 and from mut ${ }^{\circ}$ patients. Results (Table 3) showed that although control cell lines showed a marked increase in propionate incorporation under these conditions (compare Table 2) and cells from patient 10 showed supranormal activity, cells from patient 11 (and mut ${ }^{\circ}$ patients) showed no increase in propionate incorporation.

\section{DISCUSSION}

These results show that a detailed classification of (cell lines from) patients with methylmalonic aciduria may be made on the basis of direct methylmalonyl CoA mutase activity combined with propionate incorporation studies with and without the addition of cobalamin cofactors. The mutase assay used has also been used for the analysis of amniocytes and fetal fibroblasts and is suitable for direct assay of mutase activity in chorionic villus tissue. The majority of patients studied were classified as mut ${ }^{\circ}$ variants, with no detectable mutase activity in the presence of saturating cofactor concentrations. One patient could be classified as a mut ${ }^{-}$variant but was unresponsive to cobalamin therapy in vivo. Two patients were classified as $\mathrm{Cbl}$ variants, one as a $\mathrm{Cbl}$ A variant responsive to hydroxocobalamin therapy in vivo and in vitro and one as a $\mathrm{Cbl} \mathrm{B}$ variant. This latter patient (patient 11) was unresponsive to $\mathrm{OHCbl}$ therapy during her initial management after diagnosis and during the present study also failed to respond in vivo to AdoCbl therapy, despite the ability of her cell sonicates to show normal mutase activity in the presence of added cofactor. The results of studies of propionate incorporation in the presence of saturating concentrations of $\mathrm{AdoCbl}$ suggest that this cofactor is unable to enter the cells in an unchanged form and is probably hydrolyzed on uptake into the cells to $\mathrm{OHCbl}$. Cells from patient 10 were responsive to both $\mathrm{OHCbl}$ and $\mathrm{AdoCbl}$, lending support to this hypothesis. Conversion of AdoCbl to $\mathrm{OHCbl}$ by light irradiation was excluded because all studies with added cofactor were carried out in the dark.

These observations are consistent with the results reported by Batshaw et al. (7) of a trial with adenosylcobalamin in a $\mathrm{Cbl} \mathrm{B}$ patient when there was no sustained response to cofactor therapy. These authors concluded that the adenosylcobalamin did not reach the mitochondria in an intact form or that an abnormality of intramitochondrial compartmentalization or enzyme interaction prevented adequate access and binding of AdoCbl to the mutant apoenzyme. The results from studies of cells from our patient tend to exclude the latter, because normal mutase activity could be achieved in cell sonicates, and add support to the former conclusion. The apparent response to $\mathrm{OHCbl}$ or even to cyanocobalamin of some patients classified as $\mathrm{Cbl} \mathrm{B}$ mutants on the basis of complementation studies indicates the inability of complementation to delineate all the molecular variants leading to methylmalonic aciduria. Some of these patients may well have mutations affecting the activity or cofactor binding of deoxyadenosyltransferase that may be sufficiently enhanced by phar-

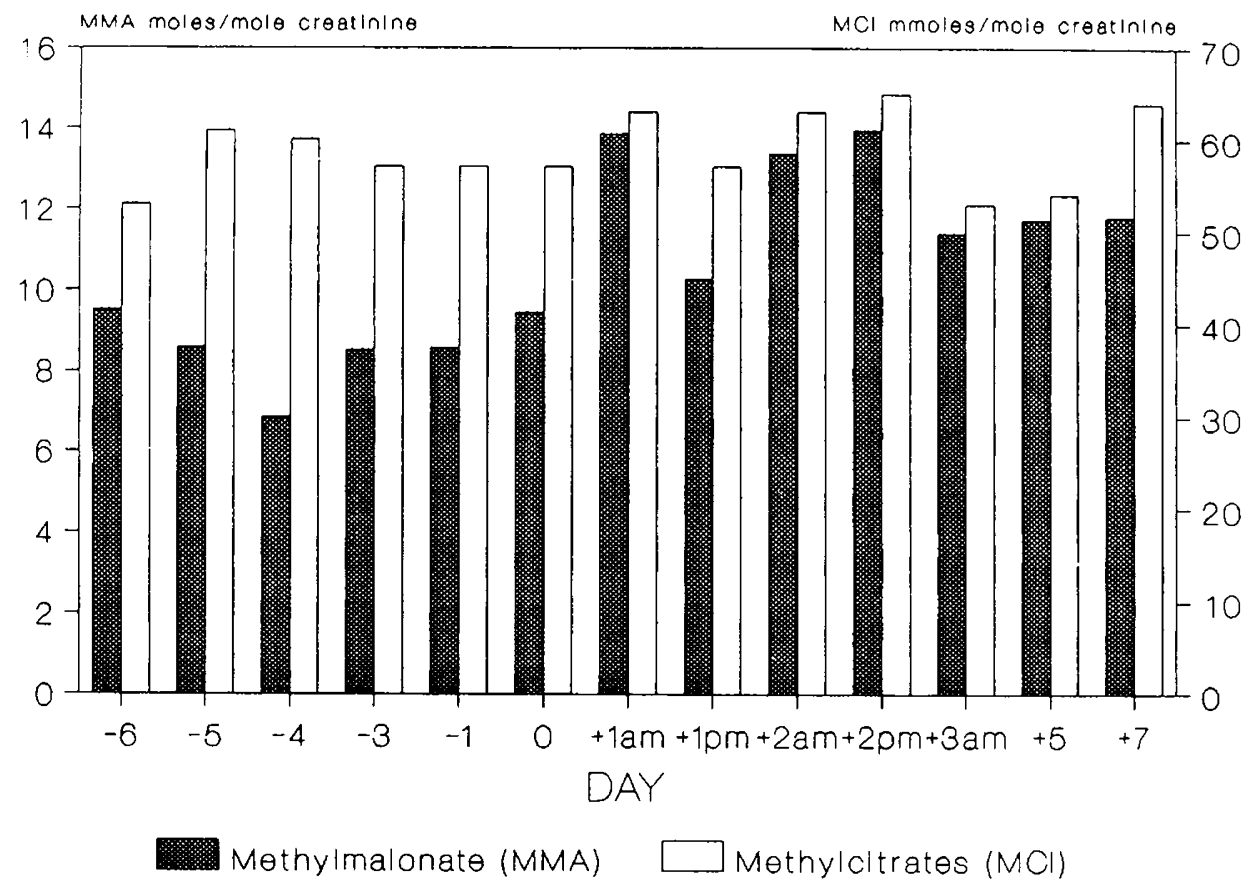

Fig. 1. Urinary excretion of methylmalonate and methylcitrates ( $2 R, 3 S$ plus $2 R, 3 R)$ by a patient before and during AdoCbl treatment. AdoCbl therapy commenced on $\mathrm{d} 0$. 
Table 3. Propionate incorporation into protein (pmol propionate incorporated $/ \mathrm{mg}$ protein $/ \mathrm{h}$ ) in intact fibroblasts in monolayer culture cultured with and without $1 \mathrm{\mu g} / \mathrm{mL}(0.633 \mu \mathrm{mol} / \mathrm{L})$ $\mathrm{AdoCbl}{ }^{*}$

\begin{tabular}{lcc}
\hline & Basal medium & + AdoCbl \\
\hline Patient 10 (Cbl A) & 86 & 397 \\
Patient 11 (Cbl B) & 20 & 24 \\
Mut patients $_{\text {Controls }}$ & 24 & 26 \\
\hline
\end{tabular}

$*_{n}=3$ lines, studied in duplicate; values are medians. All cultures and assays were carried out in the dark.

macologic doses of hydroxocobalamin rather than a total deficiency of enzyme activity; cells from such variants would not show complementation with cells from patients with total enzyme deficiency and all would be classified as " $\mathrm{Cbl} \mathrm{B"} \mathrm{mutants.}$ Our observations suggest that the minority of $\mathrm{Cbl} B$ patients who are responsive to $\mathrm{OHCbl}$ have a different molecular defect from unresponsive patients that may be revealed by further study. Our results have shown that it is unlikely that AdoCbl reaches the mitochondria in an intact form and that therapy with this form of the cofactor offers no advantage over the use of hydroxocobalamin in the treatment of patients with methylmalonic aciduria. The results reported briefly by Bhatt et al. (8) in a biochemically unclassified patient without detail of the urinary methylmalonate concentrations after treatment are difficult to interpret but suggest that this patient was in fact a mutase-deficient patient and that perhaps the methods used for monitoring were inadequate. The reported transient response to $\mathrm{OHCbl}$ is not uncommon in patients with methylmalonyl CoA mutase deficiencies and such brief, uncorroborated reports need to be treated with care.

Acknowledgments. The authors thank Margaret Jones for skilled technical assistance and Dr. J. Linnell for cobalamin measurements.

\section{REFERENCES}

1. Chalmers RA 1987 Disorders of organic acid metabolism. In: Holton JB (ed) The Inherited Metabolic Diseases. Churchill Livingstone, Edinburgh, pp $141-214$

2. Rosenberg LE, Fenton AW 1989 Disorders of propionate and methylmalonate metabolism. In: Scriver CR, Beaudet AL, Sly WS, Valle D (eds) The Metabolic Basis of Inherited Disease, 6th Ed. McGraw-Hill, New York, pp 821-844

3. Rosenblatt DS, Laframboise R, Pichette J, Langevin P, Cooper BA, Costa T 1986 New disorder of vitamin $B_{12}$ metabolism (cobalamin F) presenting as methylmalonic aciduria. Pediatrics 78:51-54

4. Shih VE, Axel SM, Tewkesbury JC, Watkins D, Cooper BA, Rosenblatt DS 1989 Defective lysosomal release of vitamin $\mathrm{B}_{12}(\mathrm{cbl} \mathrm{F})$ : a hereditary cobalamin metabolic disorder associated with sudden death. Am J Med Genet 33:555-563

5. Mahoney MJ, Bick D 1987 Recent advances in the inherited methylmalonic acidemias. Acta Paediatr Scand 76:689-696

6. Matsui SM, Mahoney MJ, Rosenberg LE 1983 The natural history of the inherited methylmalonic acidemias. N Engl J Med 308:857-861

7. Batshaw ML, Thomas GH, Cohen SR, Matalon R, Mahoney MJ 1984 Treatment of the cbl $\mathrm{B}$ form of methylmalonic acidaemia with adenosylcobalamin $\mathrm{J}$ Inherited Metab Dis 7:65-68

8. Bhatt HR, Linnell JC, Barltrop D 1986 Treatment of hydroxocobalaminresistant methylmalonic acidaemia with adenosylcobalamin. Lancet 2:465

9. Chalmers RA, Bain M, Mistry J, Jones MA, Tracey BM, Linnell JC, Weaver C 1988 Enzymological classification of patients with methylmalonic aciduria basis for a clinical trial of deoxyadenosylcobalamin in a hydroxocobalaminunresponsive patient. Abstracts of the 26th SSIEM Annual Symposium, Glasgow, p 63

10. Bain MD, Jones M, Reed PJ, Boriello SP, Tracey BM, Chalmers RA, Stacey TE 1988 Metronidazole therapy is beneficial in methylmalonic aciduria. Lancet 1:1078-1079

11. Linnell JC, Hoffbrand AV, Hussein HA-A, Wise IJ, Matthews DM 1974 Tissue distribution of coenzyme and other forms of vitamin $B_{12}$ in control subjects and patients with pernicious anaemia. Clin Sci Molec Med 46:163-172

12. Chalmers RA, Lawson AM 1982 Organic Acids in Man. The Analytical Chemistry, Biochemistry and Diagnosis of the Organic Acidurias. Chapman and Hall, London 